\title{
Effect of the Program «Caring for caretakers»: Findings of a multicenter study
}

\author{
Lucy Barrera, MSc ${ }^{1}$, Gloria Mabel Carrillo, MSc ${ }^{2}$, Lorena Chaparro, PhD², \\ Natividad Pinto, MSc ${ }^{1}$, Alberto Rodríguez, Stat ${ }^{3}$, Beatriz Sánchez, MSc ${ }^{1}$
}

\section{SUMMARY}

Objective: To assess the effectiveness of the program Caring for the Caregivers on the caring ability of family caregivers of people with chronic illnesses attended by programs coordinated by the Latin American nodes for the care of caregivers with chronically ill family members.

Methods: The study had a Quasi-experimental method with an experimental group (family caregivers that took the Program Caring for the caregivers and a control group. Data was collected with the Ngozi Nkongho's Caring Ability Inventory (CAI). The sample was taken by convenience in (8) nodes, with an average of 60-100 family caregivers for a total group of 643 individuals (417 in the experimental group and 226 in the control group). Statistical tests were used to evaluate proposals of normality and the Mann-Whitney $\mathrm{U}$ test to evaluate data.

Results: Findings report similar study groups with small differences in ages and socioeconomic levels. Family caregivers that took part in the Program significantly improved their caring ability with improvement in each of the dimensions of the caring ability.

Discussion: The effectiveness of the Program Caring for the caregivers in the caring ability of family caregivers is a significant finding that match with previous reports and it confirm the importance of having specific proposals for the care of caregivers in the Latin American context. Findings shows a strengthening of the general caring ability of family caregivers, as well as an straightening of each one of their dimensions that is favorable to the Program effect. These findings slightly differ from previous findings because in previous studies the caring ability never showed increase in all its components.

\section{Keyword: Caregivers; Chronic disease; Palliative care.}

Colomb Med. 2011; 42 (Supl 1): 35-44

Efecto del Programa «Cuidando a los cuidadores»: Resultados de un estudio multicéntrico

\section{RESUMEN}

Objetivo: evaluar la efectividad del programa «Cuidando a los cuidadores» sobre la habilidad de cuidado de cuidadores familiares de personas con enfermedad crónica atendidos por nodos vinculados a la Red Latinoamericana de Cuidado al Paciente Crónico.

Métodos: Casi experimental con grupo muestra (cuidadores que asistieron al Programa Cuidando a los cuidadores) y grupo control. Los datos se recolectaron con el Inventario de Habilidad de Cuidado (CAI) de Ngozi O. Nkongho. La muestra fue tomada en ocho (8) nodos, a conveniencia, con un promedio de entre 60 y 100 cuidadores, para un total de 643 personas (417 grupo experimental y 226 grupo control). Se utilizaron pruebas estadísticas para evaluar supuestos de normalidad y las pruebas U de Mann-Whitney para analizar los datos.

Resultados: Hay grupos de estudio similares con algunas diferencias en las edades y el nivel socioeconómico. Los cuidadores familiares que participaron en el programa mejoraron su habilidad de cuidado en forma significativa, con

1. Professor, Faculty of Nursing, Universidad Nacional de Colombia, Bogotá, Colombia. e-mail: lbarrerao@unal.edu.co rnpintoa@unal.edu.co_cbsanchezh@unal.edu.co

2. Assistant Professor, Faculty of Nursing, Universidad Nacional de Colombia, Bogotá, Colombia. e-mail: gmcarrillog@unal.edu.corolchaparrod@unal.edu.co

3. Professor and Statistics Consultant, Faculty of Nursing, Universidad Nacional de Colombia, Bogotá, Colombia. e-mail: albrodriguezr@unal.edu.co Received for publication June 30, 2009 Accepted for publication March 4, 2010 
incremento en todas las dimensiones que componen dicha habilidad.

Discusión: La efectividad del programa «Cuidando a los cuidadores» sobre la habilidad de cuidado de los cuidadores familiares, es un hallazgo significativo que concuerda con hallazgos anteriores y ratifica la importancia de contar con propuestas propias para el cuidado de los cuidadores familiares, es decir adaptadas al contexto latinoamericano. Los hallazgos muestran un fortalecimiento de la habilidad de cuidado de los cuidadores en general y en cada uno de sus componentes favorable al programa. Esto difiere ligeramente de hallazgos anteriores donde la habilidad había mostrado incremento pero no se reflejaba en todos sus componentes.

\section{Palabras clave: Cuidadores; Enfermedad crónica; Atención paliativa.}

\section{Colomb Med. 2011; 42 (Supl 1): 35-44}

In Latin America, chronic illness is a public health problem affecting increasing significant numbers of people, as well as their families and their communities ${ }^{1,2}$.

Chronic illness is characterized for lasting over six months, being associated to irreversible pathological situations, and generating limitations and incapacity ${ }^{3}$. Individuals with these types of illnesses require long periods of observation and assistance, which in most cases demand the presence and commitment of a family caregiver. The family caregiver in the person who having family ties or closeness, assumes the responsibilities of caring for the family member and participating in decision making, supervision, and support in carrying out everyday activities. Though their support, family caregivers compensate -in part- the dysfunction expressed by the patient through his illness ${ }^{4}$.

The family caregiver assumes responsibilities in caring, sometimes voluntarily and others due to the lack of a person who can do this or because of a sense of commitment in the face of the situation ${ }^{5}$. Generally, the caregiver does not have sufficient abilities for the responsibility acquired; this could be due to: lack of knowledge, difficulties in the capacity to address to make adequate decisions, or not having any sense of what has to be done or lacking the experience required for the type of work ${ }^{6-12}$. Perhaps this is why theyencounter stressful situations with emotional and physical overload, which end up greatly affecting their health ${ }^{13-16}$.

As part of the strategies to address the issue of caregivers who must care for other without having sufficient abilities, herein we designed, applied, and evaluated the positive effect of a program denominated $\left\langle\text { Cuidado a los cuidadores }{ }^{\mathbb{R}}{ } \text { (Caring for Caregivers) }\right)^{17}$. Its evaluation permitted its presentation to the Latin American Network for the Care of Chronic Patients (Red Latinoamericana de Cuidado al Paciente Crónico), which became interested in the proposal and decided to offer the program in different regions of Latin America.

\section{MATERIALS AND METHODS}

The application study and evaluation of the «Program Caring for caregivers» (PCC) was carried out between 2006 and 2008 in nodes linked to the Care of Chronic Patients in Latin America Network, which includes nine countries. The current report includes nodes from three of these countries: Colombia, Guatemala, and Panama. In Colombia, the Program was conducted in the cities of Cartagena, Santa Marta, Cúcuta, Ibagué, Girardot, and Villavicencio; en Guatemala, it was carried out in Guatemala City; and in Panamá, in Panamá City.

The design of the study was quasi-experimental with simple and control groups. The sample was taken in each node in convenience with a range between 61 and 100 adult family caregivers caring for chronically ill patients in Colombia (Cartagena: 67, Santa Marta: 100, Cúcuta: 100, Ibagué: 85, Girardot: 72, Villavicencio: 61), in Guatemala: 78 and in Panamá: 80, for a total of 643 individuals. Three meetings were held with researchers from each node where the instrument's idiomatic adaptation was performed, along with strategies for recruitment of the population and information collection, training in the application of the measuring instrument and the training program in the intervention.

To avoid information bias, the information gathered was digitized in an Access data base and purged and processed by a statistician. To control confusion variables, we parted from recognizing the notion that, currently, in Colombia and Latin America, research in nursing lacks the population frames from which random samples may be selected for use. For this reason, the study worked with groups of captive individuals in different institutions through non-random selection techniques (convenience samplings). Recognizing existing limitations, importance was assigned to the 
Table 1

Socio-demographic characteristics of the participants

\begin{tabular}{|c|c|c|c|c|c|c|c|}
\hline \multicolumn{2}{|c|}{ Characteristic } & \multicolumn{2}{|c|}{ General } & \multicolumn{2}{|c|}{ Control } & \multicolumn{2}{|c|}{ Experimental } \\
\hline & & Freq & $\%$ & Freq & $\%$ & Freq & $\%$ \\
\hline \multirow[t]{2}{*}{ Gender of caregiver } & Male & 80 & 12 & 24 & 11 & 56 & 13 \\
\hline & Female & 563 & 88 & 202 & 89 & 361 & 87 \\
\hline \multirow[t]{4}{*}{ Age of the caregiver } & 17 years old or less & 9 & 1 & 2 & 1 & 7 & 2 \\
\hline & Between 18 and 35 years of age & 164 & 26 & 74 & 33 & 90 & 22 \\
\hline & Between 36 and 59 years of age & 341 & 53 & 109 & 48 & 232 & 56 \\
\hline & 60 years old or more & 129 & 20 & 41 & 18 & 88 & 21 \\
\hline Is the caregiver & Yes & 614 & 95 & 214 & 95 & 400 & 96 \\
\hline \multirow[t]{4}{*}{ literate? } & No & 26 & 4 & 12 & 5 & 14 & 3 \\
\hline & Without information & 3 & 0 & 0 & 0 & 3 & 1 \\
\hline & Without information & 7 & 1 & 1 & 0 & 6 & 1 \\
\hline & Others & 4 & 1 & 3 & 1 & 1 & 0 \\
\hline \multirow{5}{*}{$\begin{array}{l}\text { Marital status of } \\
\text { caregivers }\end{array}$} & Single & 167 & 26 & 65 & 29 & 102 & 24 \\
\hline & Married & 248 & 39 & 78 & 35 & 170 & 41 \\
\hline & Separated & 56 & 9 & 21 & 9 & 35 & 8 \\
\hline & Widow (er) & 45 & 7 & 18 & 8 & 27 & 6 \\
\hline & Common-law marriage & 127 & 20 & 44 & 19 & 83 & 20 \\
\hline \multirow{6}{*}{$\begin{array}{l}\text { Occupation of } \\
\text { caregivers }\end{array}$} & Household & 395 & 61 & 136 & 60 & 259 & 62 \\
\hline & Employee & 89 & 14 & 28 & 12 & 61 & 15 \\
\hline & Independent Work & 108 & 17 & 39 & 17 & 69 & 17 \\
\hline & Student & 9 & 1 & 4 & 2 & 5 & 1 \\
\hline & Others & 41 & 6 & 19 & 8 & 22 & 5 \\
\hline & Without information & 1 & 0 & 0 & 0 & 1 & 0 \\
\hline \multirow{7}{*}{$\begin{array}{l}\text { Socio-economic level } \\
\text { of caregivers }\end{array}$} & Level 1 & 149 & 23 & 63 & 28 & 86 & 21 \\
\hline & Level 2 & 216 & 34 & 89 & 39 & 127 & 30 \\
\hline & Level 3 & 154 & 24 & 34 & 15 & 120 & 29 \\
\hline & Level 4 & 36 & 6 & 2 & 1 & 34 & 8 \\
\hline & Level 5 & 6 & 1 & 0 & 0 & 6 & 1 \\
\hline & Level 6 & 4 & 1 & 0 & 0 & 4 & 1 \\
\hline & Does Not Apply & 78 & 12 & 38 & 17 & 40 & 10 \\
\hline \multicolumn{2}{|l|}{ Total } & 643 & 100 & 226 & 100 & 417 & 100 \\
\hline
\end{tabular}

possible variables exposed in Table 1 (gender, age, schooling, etc). Once these were detected, we conducted a selection of caregivers from homogenous institutions, which permitted conforming relatively similar groups.

A data base was available with socio-demographic information along with the dedication of these caregivers who, on two occasions, were measured on their ability in caring. Grade points were registered for 417 caregivers before and after their participation in the intervention of the PCC (sample group) and for 226 caregivers who also received the instrument on two similar moments along time, but who did not receive this intervention; receiving instead conventional attention (control group).

The work hypotheses included:

1. There are statistically significant differences between (total) care ability of the caregivers from the experimental group and the caregivers from the control group, favorable to the PCC. 
2. There are statistically significant differences between the components of the care ability (knowledge, courage, or patience) of the caregivers from the experimental group and those from the control group, favorable to the PCC. The null hypothesis made reference to the lack of differences between the care ability of the caregivers from the sample and control groups. The hypotheses suggested were verified with a $95 \%$ level of confidence.

The PCC runs for 10 weeks, three hours per week working simultaneously with an average of 20 family caregivers. The program is organized with accompanying audiovisual and written material and structured guides in three modules according to the components of the care ability.

The intervention of the control group was made by asking users which theme or activity of their interest related to their role as care givers they wanted to treat. This group did notreceive specific educational material, except when help was requested to aid in understanding any of the issues addressed. The sessions varied according to the group interests, which on the average were 10 per group during the 12 months of the study.

The initial and final measurements of the abilities of the family care giver to offer care were done with the care ability inventory, $\mathrm{CAI}^{\circledR 18}$. This instrument has 37 items with Likert-type graduation and it is composed of three subscales: knowledge, courage, and patience. It has a validity of 0.80 and reliability of 0.84 . This reliability was ratified with Colombian population. Additionally, it included general questions to characterize the care-givers and the PULSES profile was used to make a functional assessment of the receptor. This profile permits quantifying the degree of dependence on a person and it has been successfully used as a clinical assessment tool in chronicity situations ${ }^{19}$.

Once the care ability has been assessed with the CAI, the data obtained are classified into categories of «low» or «high» care ability. Grade points for the inventory in general were considered (total ability), as for each of its three dimensions: knowledge, patience, and courage. Then a general analysis was made of the data in the groups, both in the initial test (pre-test) as in the final (post-test) from its representation through box plots and, thereafter, statistical procedures were implemented to determine the validity of the conclusions formulated from the first analysis and to define the scope of the findings established.

In order to test the care ability of the 643 caregivers, we set out to measure how far the participants were from the minimum grade possible in each of the dimensions and in the total punctuation. The criterion to judge the sufficiency of the care ability of the caregivers in the current study was established at $70 \%$ of the distance to the minimum possible punctuation.

The statistical treatment of the data and, especially those concerning the tests to evaluate assumptions of normality, like the Mann-Whitney U employed to determine if the differences in the scores of both groups are significant, were based on original scores.

The study considered the ethical aspects regarding cost benefit, the informed consent, voluntary participation, and confidential treatment of information. This Program was approved by the Research Ethics Committee from the Faculty of Nursing at Universidad Nacional de Colombia. It was evaluated as zero environmental impact.

\section{RESULTS}

Characteristics of the groups. The results reveal that the composition of both groups of caregivers is similar in most of the variables considered, except in those concerning age of caregivers and their socioeconomic levels (Table 1). In variables related to care, differences were not identified between the two groups reaching or surpassing ten percentage points; hence, it may be concluded that in the distribution of these characteristics both groups are quite comparable.

Most, from each group, cares for the person from the moment of diagnosis; almost half of the caregivers, $51 \%$, dedicate 24 hours a day to this task; nevertheless, judging from the data, the experimental group dedicates greater time to caring tan the control group and almost half the participants are supported by other caregivers (47\%), while $52 \%$ are sole caregivers. The experimental and control groups are similar in this distribution.

Among caregivers and the individuals being cared for, $63 \%$ are family members in the first degree of consanguinity; $35 \%$ of the caregivers are the father or mother, and in $28 \%$ of the cases the caregiver is a son or daughter. There is a very similar proportion among caregivers who are spouses (14\%) and those who 
Table 2

Characteristics of the care given and of the attention of the caregivers

\begin{tabular}{|c|c|c|c|c|c|c|c|}
\hline \multicolumn{2}{|c|}{ Characteristic } & \multicolumn{2}{|c|}{ General } & \multicolumn{2}{|c|}{ Control } & \multicolumn{2}{|c|}{ Experimental } \\
\hline & & Freq & $\%$ & Freq & $\%$ & Freq & $\%$ \\
\hline \multirow{3}{*}{$\begin{array}{l}\text { Cares for patient from the } \\
\text { moment of diagnosis }\end{array}$} & Yes & 565 & 88 & 202 & 89 & 363 & 87 \\
\hline & No & 78 & 12 & 24 & 11 & 54 & 13 \\
\hline & Total & 643 & 100 & 226 & 100 & 417 & 100 \\
\hline \multirow{5}{*}{$\begin{array}{l}\text { Hours per day dedicated to } \\
\text { caring for the patient }\end{array}$} & $6 \mathrm{~h}$ or less & 63 & 10 & 18 & 8 & 45 & 11 \\
\hline & 7 to $12 \mathrm{~h}$ & 140 & 22 & 60 & 27 & 80 & 19 \\
\hline & $13-23 h$ & 112 & 17 & 43 & 19 & 69 & 17 \\
\hline & $24 \mathrm{~h}$ & 327 & 51 & 105 & 46 & 222 & 53 \\
\hline & Without information & 1 & 0 & 0 & 0 & 1 & 0 \\
\hline \multirow[t]{3}{*}{ Sole caregiver? } & Yes & 336 & 52 & 107 & 47 & 229 & 55 \\
\hline & No & 303 & 47 & 117 & 52 & 186 & 45 \\
\hline & Without information & 4 & 1 & 2 & 1 & 2 & 0 \\
\hline \multirow{7}{*}{$\begin{array}{l}\text { Relationship with the } \\
\text { individual being cared (role) }\end{array}$} & Spouse & 89 & 14 & 23 & 10 & 66 & 16 \\
\hline & Mother/Father & 227 & 35 & 84 & 37 & 143 & 34 \\
\hline & Offspring & 179 & 28 & 66 & 29 & 113 & 27 \\
\hline & Grandmother/Grandfather & 39 & 6 & 16 & 7 & 23 & 6 \\
\hline & Friend & 22 & 3 & 10 & 4 & 12 & 3 \\
\hline & Other & 85 & 13 & 27 & 12 & 58 & 14 \\
\hline & Without information & 2 & 0 & 0 & 0 & 2 & 0 \\
\hline \multicolumn{2}{|l|}{ Total } & 643 & 100 & 226 & 100 & 417 & 100 \\
\hline
\end{tabular}

apparently have no kinship with the patient (13\%).

When comparing the composition of both groups in this study, it may be held that, in general terms, they are very similar inasmuch as their differences do not surpass three percentage points; however, it may be stressed that in the experimental group the proportion of married caregivers is greater than in the control group with $16 \%$ vs. $10 \%$ (Table 2$)$.

\section{EFFECTS OF THE PCC ON THE CARE ABILITY OF CAREGIVERS}

Hereinafter we will show the results for both groups (control and experimental) in both applications of CAI (pre-test and post-test) considering their scores in the generalCAI and those from each of the three dimensions.

For the purpose of initially exploring if the PCC had a positive effect on the general care abilities of the 417 caregivers conforming the experimental group, we proceeded to graph the box plots associated with the experimental group, as well as with the control group. Figure 1 shows the box plots associated to the total punctuation of the general CAI in the pre-test and in the post-test of both groups.

When comparing both box plots of the experimental group, it can be noted in Figure 1 that the variability increases in the post-test (compare the lengths of the box plots), which can be associated to the maximum scores also increasing and that the punctuation of $50 \%$ of caregivers whose scores ranged from 70 and 100 points, i.e., the maximum punctuation (Figure 1). However, to conclude that this increase is significant, we proceeded to apply the Mann-Whitney $U$ test for two independent samples.

Upon evaluating the hypothesis with a value associated to the Z-test statistic of -3.540 and $p<0.0001$, we found sufficient statistical evidence to accept the affirmation made in the alternate hypothesis. That is, in this study there is sufficient evidence to conclude that the PCC significantly increased the General Care Ability of the participating caregivers. 


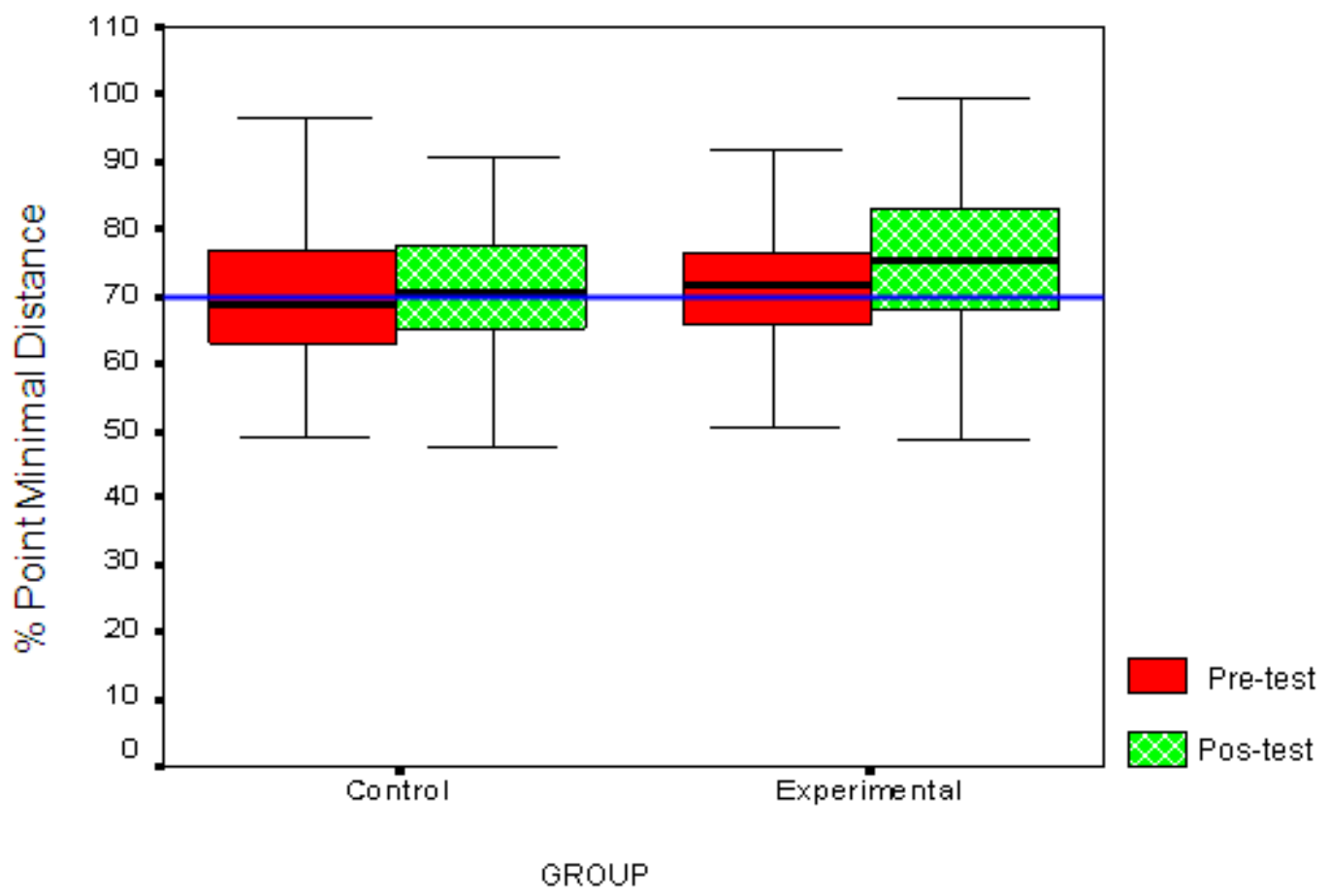

Figure 1. Representation of the general care ability of the two groups in the pre-test and in the post-test

The statistic analysis made was similarly implemented with the data obtained from each of the three constitutive dimensions of the CAI: Knowledge, Patience, and Courage (Figures 2, 3, 4).

Upon evaluating the working hypothesis with respect to the courage component of the care ability and with an estimation associated to the Z-test statistic of -2.801 and $p<0.004$, we found sufficient statistical evidence to affirm that in this study there is sufficient evidence to conclude that the PCC significantly increased the courage of the participating caregivers.

When evaluating the previous working hypothesis with respect to the knowledge component of the care ability and with an estimation associated to the Z-test of -2.523 and $\mathrm{p}=0.012$, we found sufficient statistical evidence, with $95 \%$ confidence, to accept the affirmation made in the hypothesis, i.e., in conformity with the information available in this study, it may be said that there is sufficient evidence to conclude that the PCC significantly increased the knowledge of the participating caregivers.

When evaluating the working hypothesis with respect to the component of patience of the care ability and with an estimation associated to the Z-test of -3.273 and $p=$
0.001, we found sufficient statistical evidence, with $95 \%$ confidence, to accept the affirmation madein the hypothesis, i.e., in conformity with the information available in this study, it may be said that there is sufficient evidence to conclude that the PCC significantly increased the patience of the participating caregivers.

\section{DISCUSSION}

The results of the current study revealed that the PCC favorably impacts the general care ability of caregivers, as well as the components of such: knowledge, courage, and patience. Caregivers from the experimental group participating in the intervention with the PCC showed better scores in their second measurement of the care ability than their counterparts who did not have this experience (and themselves prior to the intervention).

This central finding is especially important for several reasons. For starters, there are no previous studies that, with the methodological characteristics of the current study, have detected a significant impact of any program to increase the care abilities of the family caregivers. Also, this could be the first study obtaining the expected 


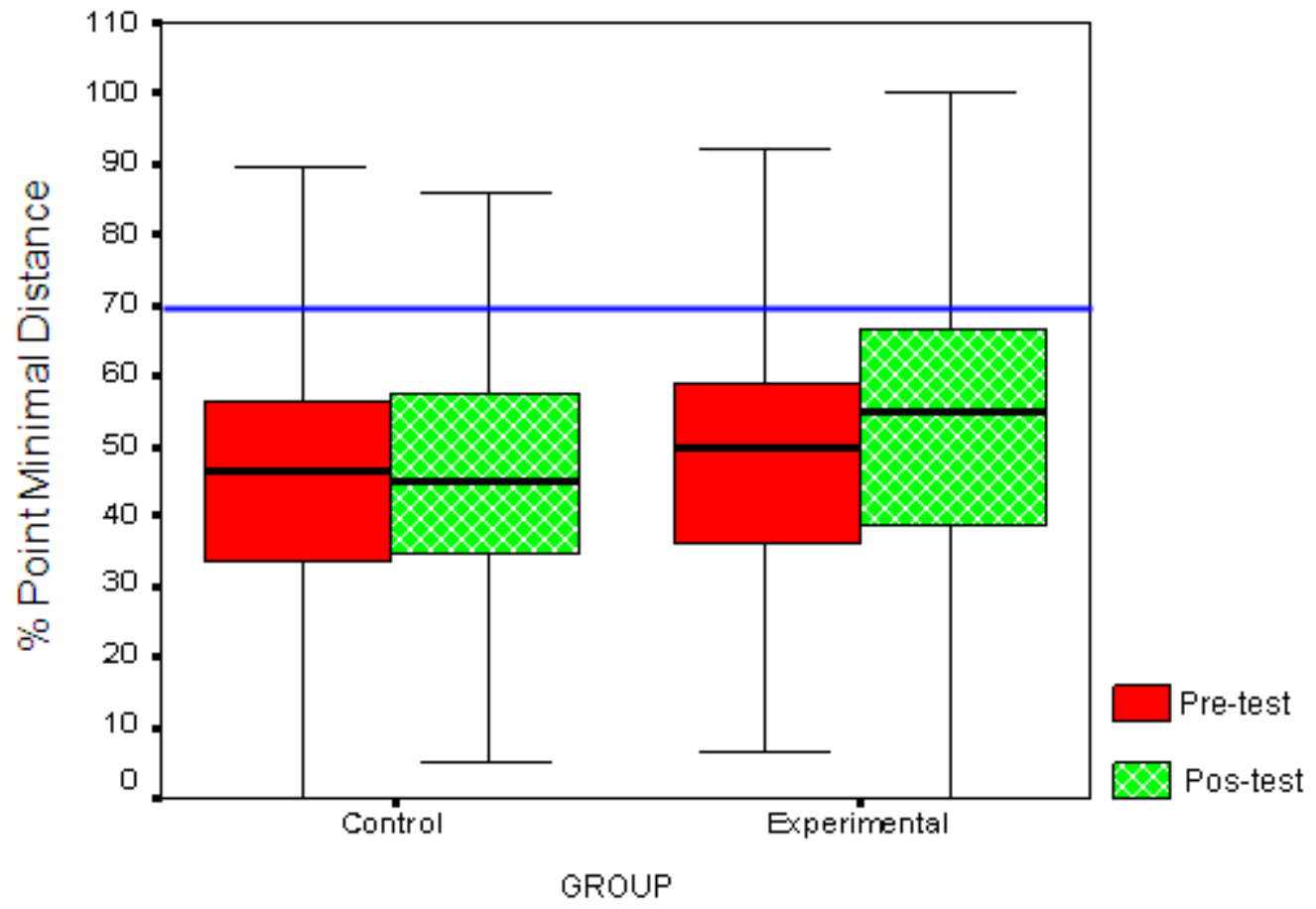

Figure 2. Representation of scores in the dimension of Courage

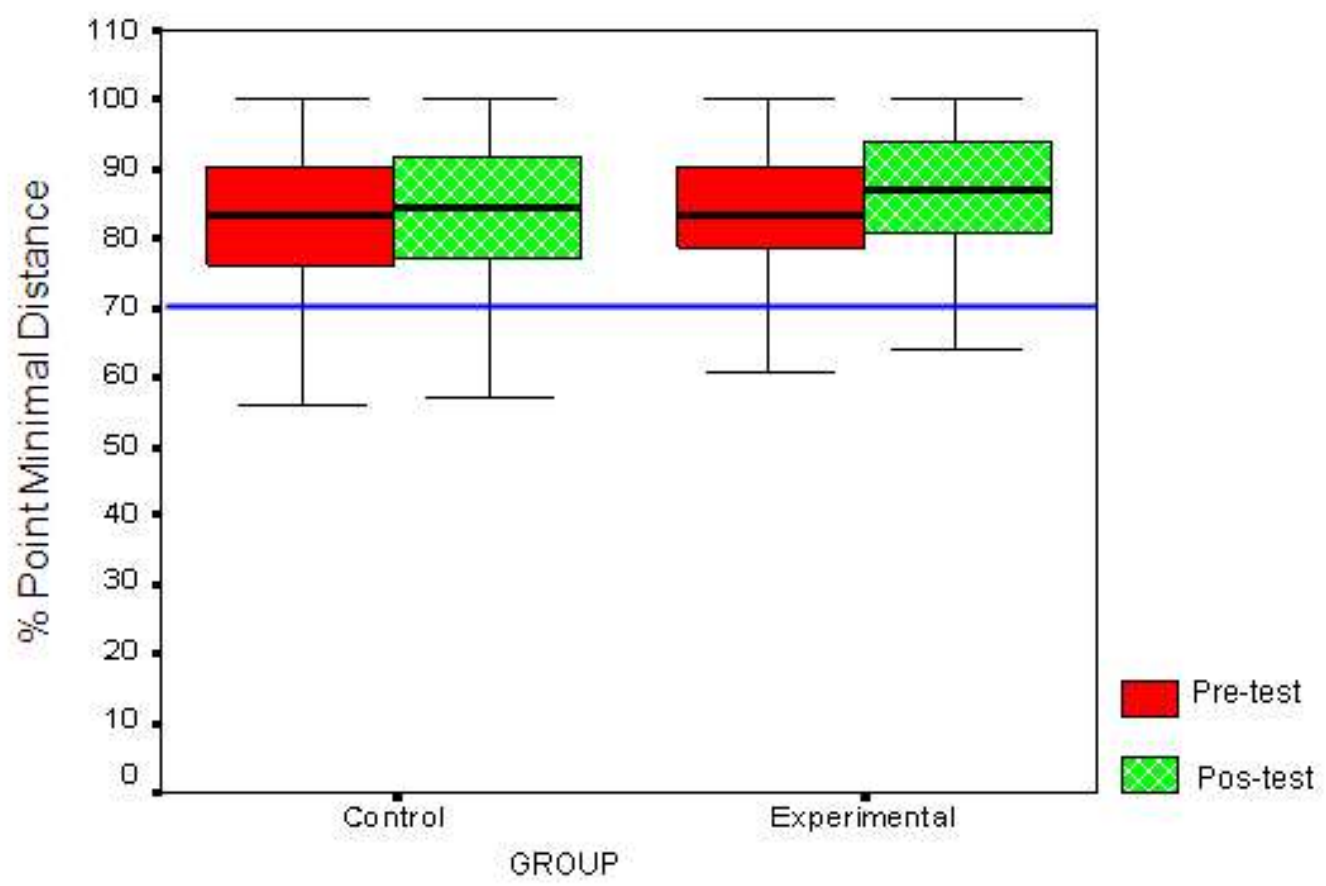

Figure 3. Representation of scores in the dimension of Knowledge of the two groups in the pre-test and in the post-test 


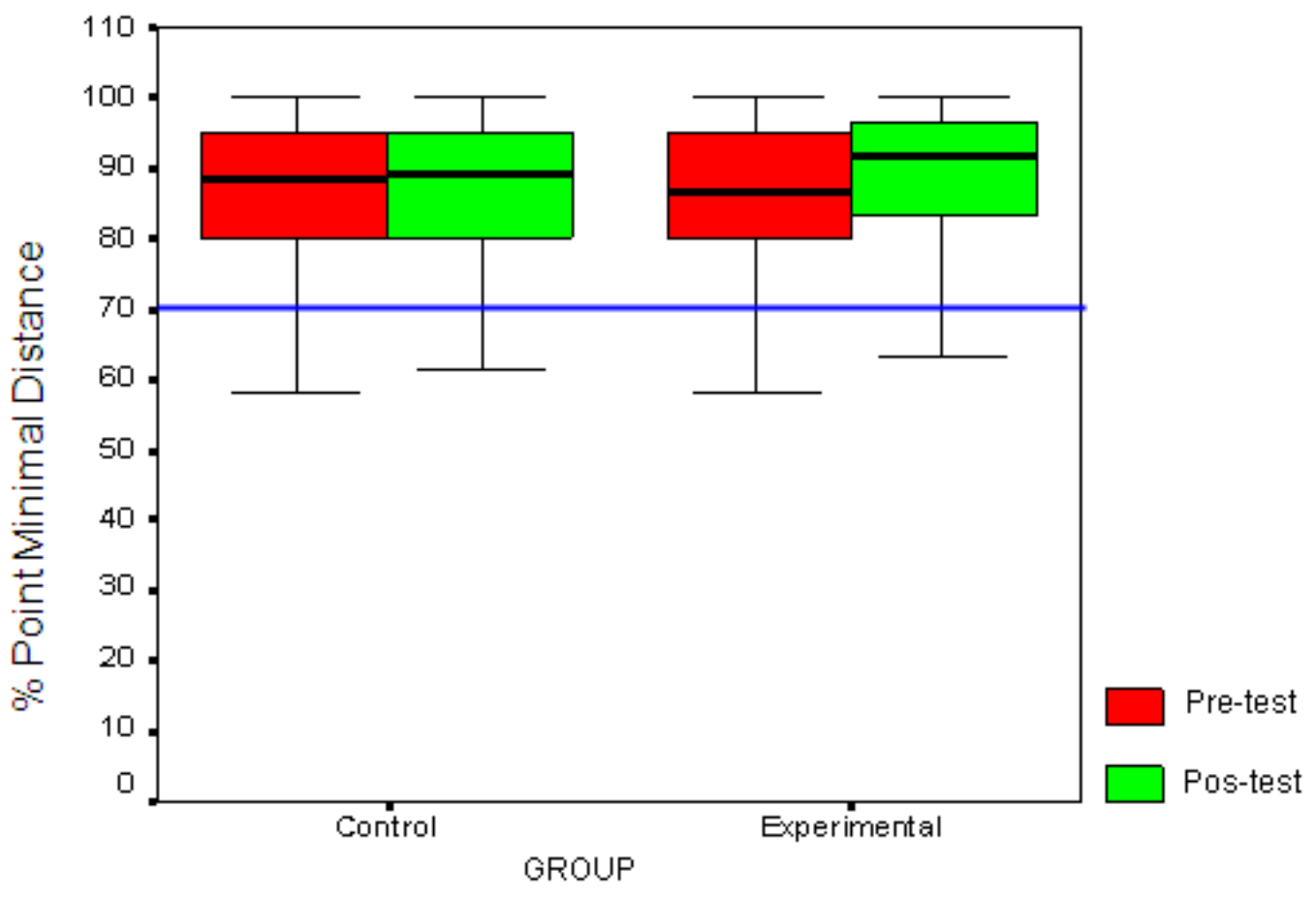

Figure 4. Representation of scores in the dimension of patience of the two groups in the pre-test and in the post-test

consistency in the results for each of the dimensions constitutive amongst themselves and of these with the results of the general ability.

The methodological characteristics associated with the vast size of the sample used may be responsible, at least partially, for the finding mentioned. Especially, the amplitude of the sample permitted for the composition of the control and experimental groups to be similar; in contrast, this initial comparison was not satisfied in studies with smaller sized samples.

Furthermore, methodological characteristics not controlled in the studies with small samples could have overshadowed the effect of the Intervention and explain, thus, why significant differences were not previously detected between the caregivers in the experimental and control groups.

This same reasoning based on the methodological benefits of the current study could be used to explain the consistency obtained in the results from each of the constitutive dimensions of the care ability, i.e., knowledge, patience, and courage of the caregivers, and in the results related to the consistency among them and the general ability. In other words, the control that enabled the size of the current simple could be a condition favored the identification of the empirical consistency detected that was conceptually and methodologically expected among the general ability and its components, and which were not previously detected.

The preceding considerations insinuate, then, that the findings of the current study should be explained (in the first instance) in relation to the PCC. So, it is convenient to recommend that teams of health professionals and researchers who have opted for applying the PCC continue with efforts aimed at enhancing this type of intervention designed by nursing to work with those caring for chronically ill individuals within the Latin American context. Work in this direction will enable formalizing the knowledge that nursing professionals purposefully construct through their work with the community.

Another important finding agreeing with the current research interests refers to the relative but important stability in the data obtained from the control group. In effect, the data from the general base employed permitted detecting this effect, in contrast to studies with smaller 
samples that manage to establish the difference between the changes of the experimental group and the relative stability expected from the caregivers from the control group who do not participate in the Program. ${ }^{6-9,11-12,17}$. It is, nevertheless, significant that in other studies, caregivers from the experimental groups increased their scores and, to a lesser degree, so did those from the control group. So, it was clearly found that the caregivers from the control group kept their initial behavior stable and those from the experimental group significantly improved their evaluated care ability.

In any case, it should not be dismissed that the variables related to the ages of the caregivers and their socio-economic levels had some incidence over the results obtained. In the first place, in these two variables both groups presented some differences worth considering and, in the second place, those in the experimental group were in principle more favored with respect to the variable related to the socio-economic condition.

Future studies could employ the same information to explore important relationships between the sociodemographic characteristics and the scores on care ability obtained during two periods of time. One of these could consist, for example, in establishing if prior to any intervention were there any differences or factors associated with the high or low scores of the caregivers in their care ability and in each of the dimensions. That is, we are proposing to take advantage of the current data base to trace new analysis and interpretation criteria that contribute to explaining the effects of the intervention, as well as to eventually identifying the profiles of the caregivers. To this effect, it is recommended that, whenever possible, the collection of new information enhances the data base available, addressing variables like types of illnesses of patients being cared by the caregivers and the geographical zone. Previous studies have insinuated that these are two variables that can be of importance.

In spite of the methodological limitations in other studies that have explored the care abilities of caregivers, said studies have proposed interesting relationships that could be subjected to investigative analysis with the general database used in this study. One of these has to do with the possible factors associated with the high or low care abilities of caregivers before and after the intervention. Particularly, it could be asked if with the base of 643 participants, if it is possible to replicate the tendencies observed in the study conducted with caregivers from the Colombian Atlantic Coast. In this study, researchers found that gender seems to be a factor associated with patience (women tend to score better than men), but not associated with knowledge (scores for women and men are similar); that the condition of being the sole caregiver seems to also make for better levels of patience, but without incidence on better knowledge; being a care-giving daughter seems related to favorable scores in patience and knowledge; caregivers with lower levels of schooling and from lower socio-economic levels have the highest scores in patience than their counterparts (higher level of schooling and high socio-economic levels); notwithstanding, schooling and socio-economic condition (according to level) did not manage to discriminate, in defined manner, the knowledge of the caregivers.

Although the current study detected as significant the differences obtained in the courage dimension between both study groups, it seems opportune to discuss the inconsistency detected in most related studies with respect to the general results and those from the dimensions of knowledge and patience and those from the dimension of courage. The consistency found in this study can become an important referent for the discussion recommended.

The authors declare having no conflict of interest with the Division of Research (DIB9, (División de Investigación de la Sede Bogotá, Universidad Nacional de Colombia), which was the funding institution. It should be stated that each node is free to publish its partial results and that the central research group designed and guided the research process encompassing this production.

Conflict of interest.The program «Caring for caregivers» is registered with the National Copyright Direction (Dirección Nacional de Derechos de Autor) in Book 10 Vol. 155, Part 79 of 03 January 2007.

\section{REFERENCES}

1. Organización Panamericana de la Salud. Salud en las Américas. Vol. 1. Washington, DC: OPS; 2007.

2. Sánchez B. El cuidado de la salud de personas que viven situaciones de enfermedad crónica en América Latina. Actual Enferm. 2002; 5: 13-6.

3. Vidaver V. Concepts in chronic illness and home care. En: 
Helvie C (ed.). Comunity health nursing. Theory and practice. New York: Springer Publishing Company; 1991. p. 271-88.

4. Pinto N, Barrera L, Sánchez B. Reflexiones sobre el cuidado a partir del programa Caring for caretakers. Aquichan. 2005; 5: $128-37$.

5. Barrera L. El cuidado del cuidador que afronta enfermedades crónicas. En: Grupo de cuidado. Cuidado y práctica de enfermería. Bogotá: Universidad Nacional de Colombia, Unibiblos; 2000. p. 233-7

6. Barrera L, Blanco L, Figueroa P, Pinto N, Sánchez B. Habilidad cuidadores con enfermedad crónica. Mirada internacional. Aquichan. 2006; 6: 22-33.

7. Barrera L, Galvis M L, Moreno ME, Pinto N, Pinzón ML, Sánchez B. La habilidad de cuidado de los cuidadores familiares de personas con enfermedad crónica: un estudio comparativo de tres unidades académicas de enfermería. Invest Edu Enferm. 2006; 24: 36-46.

8. Díaz JC. Habilidad de cuidado de un grupo de cuidadores familiares de personas con enfermedad crónica que se encuentran vinculados al Hospital San Rafael de Girardot. [Tesis de Maestría en Enfermería]. Bogotá: Universidad Nacional de Colombia; 2006.

9. Ramos E. Habilidad de cuidado de los cuidadores de persona con cáncer del Instituto Cancerológico del Magdalena y de la Fundación de Oncología del Caribe. [Tesis de Maestría en Enfermería]. Bogotá: Universidad Nacional de Colombia; 2007.

10. Amador C. Habilidad de cuidado de cuidadores familiares de enfermos mentales que residen en el área urbana de Montería; el periodo del estudio estuvo comprendido entre los meses mayo a julio del 2006. [Tesis de Maestría en Enfermería]. Bogotá: Universidad Nacional de Colombia; 2007.
11. Ripoll LD. Habilidad de cuidado de cuidadores familiares de pacientes con Alzhaimer que asistieron al Centro Neurológico de Córdoba en los meses de julio a septiembre del 2006 · [Tesis de Maestría en Enfermería]. Bogotá: Universidad Nacional de Colombia; 2007.

12. Montalvo A. Familiares cuidadores de pacientes con Alzheimer. Universidad Nacional de Colombia. [Tesis de Maestría en Enfermería]. Bogotá: Universidad Nacional de Colombia; 2006.

13. Moreno ME; Nader A, López C.Relación entre las características de los cuidadores familiares de pacientes con discapacidad y la percepción de su estado de salud. Av Enferm. 2004; 22: 2738.

14. Barrera L. La cronicidad y el cuidado familiar, un problema durante la niñez. Av Enferm. 2004; 22: 46-52.

15. Pinto N. La cronicidad y el cuidado familiar, un problema de todas las edades: los cuidadores de adultos. Av Enferm. 2004; 22: 53-9.

16. Sánchez B. La cronicidad y el cuidado familiar, un problema de todas las edades: los cuidadores de ancianos. Av Enferm. 2004; 22: 60-4.

17. Barrera L, Pinto R, Sánchez B. Evaluación de un programa para fortalecer a los cuidadores familiares de los enfermos crónicos. Rev Salud Publica. 2006; 8: 141-52.

18. Nkongho N. The caring ability inventory. En: Strickland OL, Dilorio C (eds). Vol. 4. Measurement of nursing outcomes, measuring client self-care and coping skills. New York: Springer publishing company; 1999; p. 184-99.

19. Granger C, Greer D, Liset E, Coulombe J, O'Brien E. Measurement of outcomes of care for stroke patients. Stroke. 1975; 6: 34-41. 